\title{
Kinetics and mechanisms of oxidation of d-fructose and $d$-lactose by permanganate ion in an acidic medium
}

\author{
Rafia Azmat ${ }^{1 *}$, Raheela Naz ${ }^{1}$, Noshab Qamar ${ }^{2}$, Imran Malik ${ }^{3}$ \\ ${ }^{1}$ Department of Chemistry, University of Karachi, Karachi, Pakistan; ${ }^{2}$ Corresponding Author: rafiasaeed200@yahoo.com \\ ${ }^{2}$ Department of Chemistry, Jinnah University for Women, Karachi, Pakistan \\ ${ }^{3}$ International Centre of Chemical and Biological Sciences (ICCBS), University of Karachi, Karachi, Pakistan
}

Received 5 March 2012; revised 7 April 2012; accepted 20 April 2012

\begin{abstract}
The oxidations of D-fructose and D-lactose were monitored spectrophotometrically by potassium permanganate in acidic medium at $\lambda_{\max } 545 \mathrm{~nm}$. Reaction demonstrated that the two oxidative species of permanganate were involved in an acidic oxidation of the sugars. It was established that respective acids of sugars as well as arabinonic and formic acid were the oxidation products. Respective acids of sugars were the results of reactive oxygen species of permanganate ions in acidic conditions while arabinonic and formic acids due to the cleavage of C _ C bond through $\mathrm{MnO}_{4}^{-}$species. It was first order kinetics with respect to [ $\mathrm{MnO}_{4}^{-}$], [fructose], [lactose] and $\left[\mathrm{H}^{+}\right] . \mathrm{Hg}$ was used to accelerate the slow oxidation of lactose. Effect of varying salt electrolyte concentration was insignificant showing that the molecular species was involved in the rate determining step. Formic and arabinonic acids and respective acids were analyzed through spot and spectroscopic studies respectively. Reaction was monitored at different temperatures and thermodynamics activation parameters were determined. A mechanism consistent with kinetic studies, spectral evidences, stoichiometry of the reactions and product analysis has been proposed for the oxidation of fructose and lactose in absence and presence of catalyst respectively.
\end{abstract}

Keywords: Fructose; Lactose; $\mathrm{KMnO}_{4}$; $\mathrm{Hg}$; Formic Acid; Arabinonic Acid

\section{INTRODUCTION}

Carbohydrates are the fuel of life, being the main energy source for living organisms and the central pathway of energy storage and supply for most cells. The study of the carbohydrates and their derivatives has greatly enriched chemistry, particularly with respect to the role of molecular shape and conformation in chemical reactions [1]. Fructose or fruit sugar plays an important role, in mammalian metabolism. It is generally regarded as being 1.73 times as sweet as sucrose [2,3]. Lactose or milk sugar makes up around $2 \%-8 \%$ of milk (by weight), although the amount varies among species and individuals. Pure lactose and lactose-containing dairy by-products have markedly increased. Purified lactose can also be purchased as high calorie diet additive [4]. These biological and economic importances of the carbohydrates and especially the monosaccharides and disaccarides have been largely responsible for the interest in the study of their bio- and physiochemical properties and reactivities [5].

The kinetics of oxidation of sugars by a variety of oxidants have been reported [5-7] in both acidic and alkaline media. Several different mechanisms showing the importance of enediols, cyclic forms of sugars, etc. have been established. Studies involving the oxidation of the sugars by metal ions or their complexes in an alkaline medium are limited $[8,9]$.

The oxidation potential of $\mathrm{KMnO}_{4}$ as an oxidant is very rarely used for the oxidation of sugars, only few reports were available which discussed the oxidation of sugars and almost all applications of potassium permanganate exploit its oxidizing properties [10], since as a strong oxidant it does not generate toxic by-products. Under acidic condition the $\mathrm{KMnO}_{4}$ oxidizes alkene and aldehydes to carboxylic acids [11,12].

The objective of the current research was to study the kinetics of oxidation of fructose and lactose by $\mathrm{KMnO}_{4}$ spectrophotometrically in an acidic medium under various operational parameters to establish the pathway of reaction on the basis of kinetic data and spectroscopic analysis. 


\subsection{Experimental}

All stock solutions for kinetic investigations were prepared in double distilled water. D-fructose, D-lactose, potassium permanganate, sulphuric acid and potassium nitrate used were of Merck, $\mathrm{BDH}$ and AR grade. $\mathrm{H}_{2} \mathrm{SO}_{4}$ and $\mathrm{KNO}_{3}$ were used to maintain the required acidity and ionic strength respectively. All reactions were studied at constant temperature i.e. $32^{\circ} \mathrm{C}$ on a thermostatic water bath. The reaction was initiated by adding sugar solution to the reaction mixture and monitored spectrophotometrically at $545 \mathrm{~nm}$.

Beer Lambert law $(A=\varepsilon c l)$ was used to analyze the experimental data. According to the Beer-Lambert law, the absorbance $(A)$ of a dilute solution is proportional to its concentration, $c$ and path length $l$, where $\varepsilon$ is molar absorptivity. Change in optical density of $\mathrm{MnO}_{4}^{-}$was used as reaction monitoring tool at different optimum conditions. Rates of reaction were determined from plots of optical density against time $(t)$ where as a plot of $\ln A_{o}$ - $A_{\infty} / A_{t}-A_{\infty}$ was used to determine pseudo-first-order rate constant $(k) . \ln A_{o}-A_{\infty} / A_{t}-A_{\infty}=k t$, where $A_{o}, A_{t}$, and $A_{\infty}$ represents optical density at beginning, at time $t$ and infinity respectively.

\subsection{Stoichiometry and Product Analysis}

Varying $\left[\mathrm{MnO}_{4}^{-}\right]$and [Sugar] ratios were equilibrated at room temperature for $12 \mathrm{hrs}$ with conditions $\left[\mathrm{MnO}_{4}^{-}\right] \gg[$ Sugar $]$. Estimation of residual $\left[\mathrm{MnO}_{4}^{-}\right]$in different sets showed that $1 \mathrm{~mol}$ of sugar consumed 2 (for fructose) and 4 (for lactose) moles of $\mathrm{MnO}_{4}^{-}$. Following stoichiometric equations could be established.

$$
\begin{aligned}
& \text { Cructose } \mathrm{C}_{6} \mathrm{H}_{12} \mathrm{O}_{6}+2 \mathrm{MnO}_{4}^{-} \stackrel{\mathrm{H}^{+}}{\longrightarrow} \mathrm{C}_{5} \mathrm{H}_{10} \mathrm{O}_{6}+\mathrm{HCOOH}+2 \mathrm{MnO}_{3}^{-} \\
& \text {Arabinonic acid Formic acid } \\
& \mathrm{C}_{12} \mathrm{H}_{22} \mathrm{O}_{11}+4 \mathrm{MnO}_{4}^{-}+\mathrm{H}_{2} \mathrm{O} \stackrel{\text { H }}{\stackrel{\mathrm{H}^{+} / \mathrm{Hg}^{+2}}{\longrightarrow}} 2 \mathrm{C}_{5} \mathrm{H}_{10} \mathrm{O}_{6}+2 \mathrm{HCOOH}+4 \mathrm{MnO}_{3}^{-} \\
& \text {Lactose } \\
& \mathrm{C}_{6} \mathrm{H}_{12} \mathrm{O}_{6}+2 \mathrm{MnO}_{4}^{-} \stackrel{\mathrm{H}^{+}}{\longrightarrow} \mathrm{C}_{6} \mathrm{H}_{10} \mathrm{O}_{7}+\mathrm{H}_{2} \mathrm{O}+2 \mathrm{MnO}_{3}^{-} \\
& \text {Fructose } \\
& \mathrm{C}_{12} \mathrm{H}_{22} \mathrm{O}_{11}+4 \mathrm{MnO}_{4}^{-} \stackrel{\mathrm{H}^{+} / \mathrm{Hg}^{+2}}{\longrightarrow} 2 \mathrm{C}_{12} \mathrm{H}_{18} \mathrm{O}_{13}+2 \mathrm{H}_{2} \mathrm{O}+4 \mathrm{MnO}_{3}^{-} \\
& \text {Lactose } \\
& \text { Lacturic acid }
\end{aligned}
$$

The main products of oxidation like formic and arabinonic acids were identified by TLC and by conventional spot test methods [13] while other oxidation products i.e. fructuronic acid and lacturic acids were identified by Fab mass, ${ }^{1} \mathrm{H}-\mathrm{NMR}$ and ${ }^{13} \mathrm{C}-\mathrm{NMR}$ spectroscopy.

\section{RESULTS}

The oxidation reaction for D-fructose and D-lactose with $\mathrm{KMnO}_{4}$ has been carried out at a constant ionic strength maintained by using $\mathrm{KNO}_{3}$. The reaction was followed by the change in optical density of $\mathrm{KMnO}_{4}$ in the reaction mixture at $\lambda_{\max } 545 \mathrm{~nm}$. The rate constants were calculated from the slope of the plot of $\ln A_{o}-$ $A_{\infty} / A_{t}-A_{\infty}$ against time. The rate data was obtained in the form of pseudo-first order rate constant. Kinetic results obtained with the variation of $\mathrm{MnO}_{4}^{-}$from $1 \times$ $10^{-3}-5 \times 10^{-3} \mathrm{~mol} \cdot \mathrm{dm}^{-3}$ were presented in the Tables 1 and 2. It was clear from the data that the rate of oxidation of both the sugars was directly proportional to $\left[\mathrm{MnO}_{4}^{-}\right]$ throughout its variation. A plot of $\log k$ against $\log$ $\left[\mathrm{MnO}_{4}^{-}\right]$(Figure 1) gives straight line with a slope near unity (0.94 and 1.2 in fructose and lactose respectively) that also confirms the first order dependence on $\mathrm{MnO}_{4}^{-}$.
The effect of change in concentration of sugars was monitored by keeping other parameters constant and found first order dependence on the substrate (Tables 1 and 2). These findings were confirmed by the plots of $\mathrm{k}$ against [sugar] (Figure 2). The rate of oxidation of lactose was enhanced by adding $\mathrm{Hg}$ catalyst. A plot of $\log k$ against log [sugar] gives straight lines (Figure 3) with slope equal to 0.84 and 1.2 for fructose and lactose respectively, showing that the order of reaction was approximately unity with respect to both sugars.

Oxidation reactions of sugars were increased in presence of an acid (Tables 1 and 2); showing that the oxidation of sugar takes place through generated reactive oxygen species in solution [14]. A plot of $k$ against $\left[\mathrm{H}^{+}\right]$ was linear with positive intercept on y-axis (Figure 4) for all the substrates which confirms an acid dependence of $\mathrm{H}^{+}$ions concentration.

Effect of change in varying electrolyte concentration was monitored to establish the nature of intermediate species in rate determine step by $\mathrm{KNO}_{3}$. It was observed that the change in an ionic strength of the medium does not alter the rate constant (Tables 1 and 2). The absence of salt effect indicates that the reaction does not take place 
Table 1. Effect of variations of $\left[\mathrm{MnO}_{4}^{-}\right]$, [fructose], $\left[\mathrm{H}_{2} \mathrm{SO}_{4}\right]$ and ionic strength of the medium on the rate of oxidation at $32^{\circ} \mathrm{C}$.

\begin{tabular}{|c|c|c|c|c|}
\hline$\left[\mathrm{KMnO}_{4}\right] \times 10^{3}\left(\mathrm{~mol} \cdot \mathrm{dm}^{-3}\right)$ & {$[$ Fructose $] \times 10^{2}\left(\mathrm{~mol} \cdot \mathrm{dm}^{-3}\right)$} & {$\left[\mathrm{H}_{2} \mathrm{SO}_{4}\right] \times 10^{1}\left(\mathrm{~mol} \cdot \mathrm{dm}^{-3}\right)$} & {$\left[\mathrm{KNO}_{3}\right]\left(\mathrm{mol} \cdot \mathrm{dm}^{-3}\right)$} & $\mathrm{k} \times 10^{3}\left(\mathrm{~s}^{-1}\right)$ \\
\hline 1.0 & 4.0 & 1.0 & 0.3 & 4.5 \\
\hline 2.0 & 4.0 & 1.0 & 0.3 & 7.5 \\
\hline 3.0 & 4.0 & 1.0 & 0.3 & 11.9 \\
\hline 4.0 & 4.0 & 1.0 & 0.3 & 15.4 \\
\hline 5.0 & 4.0 & 1.0 & 0.3 & 20.3 \\
\hline 1.0 & 1.0 & 1.0 & 0.3 & 2.3 \\
\hline 1.0 & 2.0 & 1.0 & 0.3 & 4.4 \\
\hline 1.0 & 3.0 & 1.0 & 0.3 & 5.9 \\
\hline 1.0 & 4.0 & 1.0 & 0.3 & 7.2 \\
\hline 1.0 & 5.0 & 1.0 & 0.3 & 8.3 \\
\hline 1.0 & 4.0 & 1.0 & 0.3 & 17.3 \\
\hline 1.0 & 4.0 & 2.0 & 0.3 & 17.3 \\
\hline 1.0 & 4.0 & 3.0 & 0.3 & 24.3 \\
\hline 1.0 & 4.0 & 4.0 & 0.3 & 24.3 \\
\hline 1.0 & 4.0 & 5.0 & 0.3 & 27.0 \\
\hline 1.0 & 4.0 & 1.0 & 0.3 & 7.4 \\
\hline 1.0 & 4.0 & 1.0 & 0.5 & 7.7 \\
\hline 1.0 & 4.0 & 1.0 & 0.7 & 7.2 \\
\hline 1.0 & 4.0 & 1.0 & 0.9 & 7.6 \\
\hline 1.0 & 4.0 & 1.0 & 1.1 & 7.5 \\
\hline
\end{tabular}

Table 2. Effect of variations of $\left[\mathrm{MnO}_{4}^{-}\right]$, [lactose], $\left[\mathrm{H}_{2} \mathrm{SO}_{4}\right]$ and ionic strength of the medium on the rate of oxidation at $32^{\circ} \mathrm{C}$.

\begin{tabular}{|c|c|c|c|c|}
\hline$\left[\mathrm{KMnO}_{4}\right] \times 10^{3}\left(\mathrm{~mol} \cdot \mathrm{dm}^{-3}\right)$ & {$\left[\right.$ Fructose] $\times 10^{2}\left(\mathrm{~mol} \cdot \mathrm{dm}^{-3}\right)$} & {$\left[\mathrm{H}_{2} \mathrm{SO}_{4}\right] \times 10^{1}\left(\mathrm{~mol} \cdot \mathrm{dm}^{-3}\right)$} & {$\left[\mathrm{KNO}_{3}\right]\left(\mathrm{mol} \cdot \mathrm{dm}^{-3}\right)$} & $\mathrm{k} \times 10^{3}\left(\mathrm{~s}^{-1}\right)$ \\
\hline 1.0 & 3.0 & 1.0 & 0.3 & 1.2 \\
\hline 2.0 & 3.0 & 1.0 & 0.3 & 1.6 \\
\hline 3.0 & 3.0 & 1.0 & 0.3 & 2.8 \\
\hline 4.0 & 3.0 & 1.0 & 0.3 & 7.2 \\
\hline 5.0 & 3.0 & 1.0 & 0.3 & 8.9 \\
\hline 1.0 & 1.0 & 1.0 & 0.3 & 1.2 \\
\hline 1.0 & 2.0 & 1.0 & 0.3 & 1.6 \\
\hline 1.0 & 3.0 & 1.0 & 0.3 & 2.8 \\
\hline 1.0 & 4.0 & 1.0 & 0.3 & 7.2 \\
\hline 1.0 & 5.0 & 1.0 & 0.3 & 8.9 \\
\hline 1.0 & 3.0 & 1.0 & 0.3 & 1.4 \\
\hline 1.0 & 3.0 & 2.0 & 0.3 & 2.1 \\
\hline 1.0 & 3.0 & 3.0 & 0.3 & 2.2 \\
\hline 1.0 & 3.0 & 4.0 & 0.3 & 2.5 \\
\hline 1.0 & 3.0 & 5.0 & 0.3 & 2.5 \\
\hline 1.0 & 3.0 & 1.0 & 0.3 & 3.5 \\
\hline 1.0 & 3.0 & 1.0 & 0.5 & 3.7 \\
\hline 1.0 & 3.0 & 1.0 & 0.7 & 3.7 \\
\hline 1.0 & 3.0 & 1.0 & 0.9 & 3.9 \\
\hline 1.0 & 3.0 & 1.0 & 1.1 & 3.7 \\
\hline
\end{tabular}




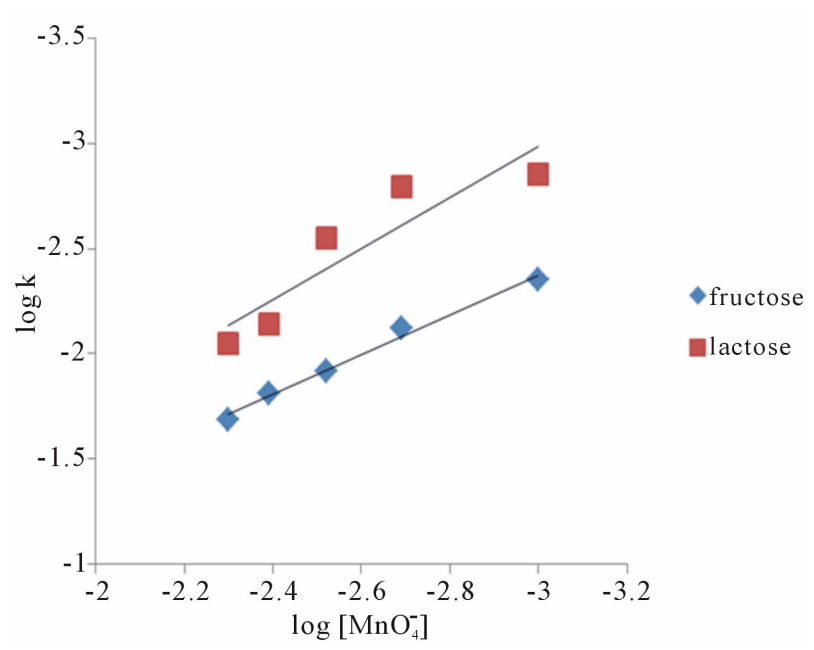

Figure 1. A plot of $\log \mathrm{k}$ vs $\log \left[\mathrm{MnO}_{4}^{-}\right]$for the oxidation of fructose and lactose.

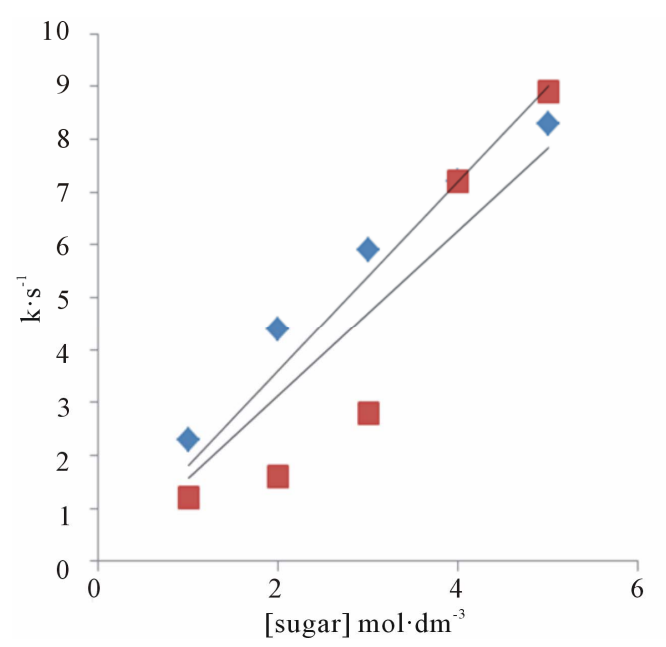

Figure 2. A plot of k vs [Sugar] for the oxidation of fructose and lactose by $\mathrm{KMnO}_{4}$.

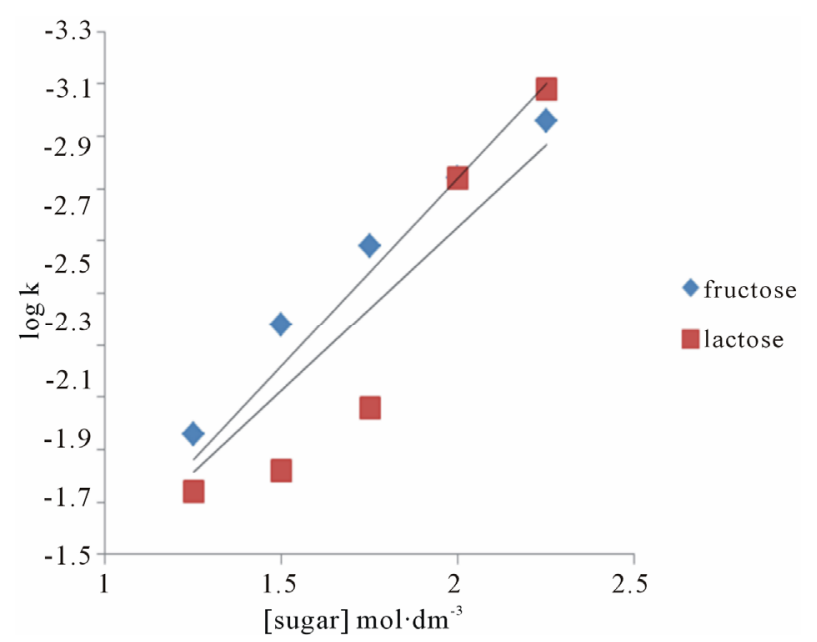

Figure 3. A plot of $\log \mathrm{k}$ vs $\log$ [Sugar] for the oxidation of fructose and lactose by $\mathrm{KMnO}_{4}$. between ionic species. Hence, at least one of the reacting species in rate determining step was molecular in nature or non-ionic [15]. The slope of the plots between $\log k$ against $\sqrt{\mu}$ (Figure 5) was zero which confirms the presence of the molecular species in rate determining step.

To evaluate the effect of temperature on rate constant, the oxidation of sugars was carried out at variable temperatures from $30^{\circ} \mathrm{C}-50^{\circ} \mathrm{C}$. It was found that the pseudo-first order rate constants increased with an increase in the temperature (Table 3) i.e. the reactions obey Arrhenius plot (Figure 6). Observed values of the rate constants at $30^{\circ} \mathrm{C}, 35^{\circ} \mathrm{C}, 40^{\circ} \mathrm{C}, 45^{\circ} \mathrm{C}$ and $50^{\circ} \mathrm{C}$ were utilized to calculate $\mathrm{E}_{\mathrm{a}}, \Delta \mathrm{H}^{\#}, \Delta \mathrm{S}^{\#}, \Delta \mathrm{G}^{\#}$ (Table 4). The extraordinary negative value of entropy of activation indicates highly solvated state of transition complex showing great degree of freedom of molecules in the transition state as

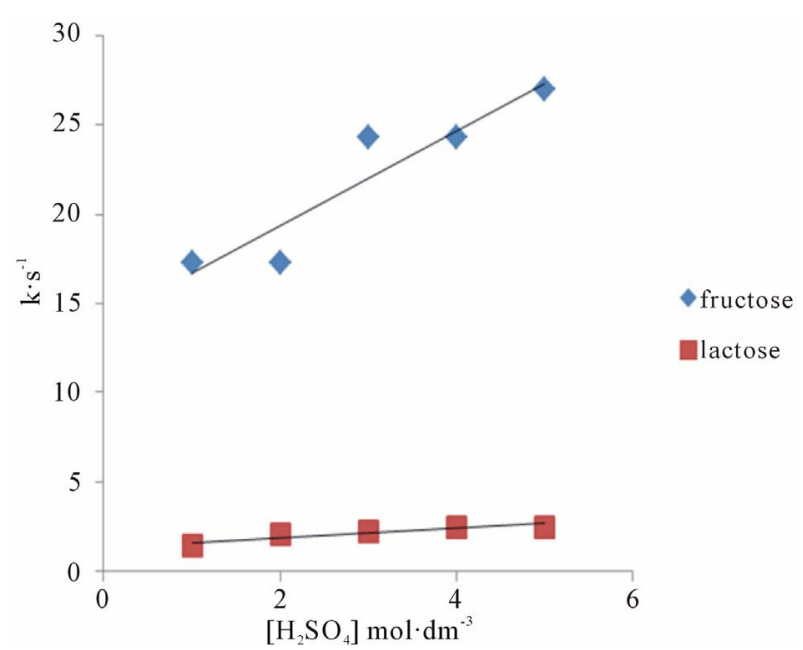

Figure 4. A plot of $\mathrm{kvs}\left[\mathrm{H}_{2} \mathrm{SO}_{4}\right]$ for the oxidation of fructose and lactose by $\mathrm{KMnO}_{4}$.

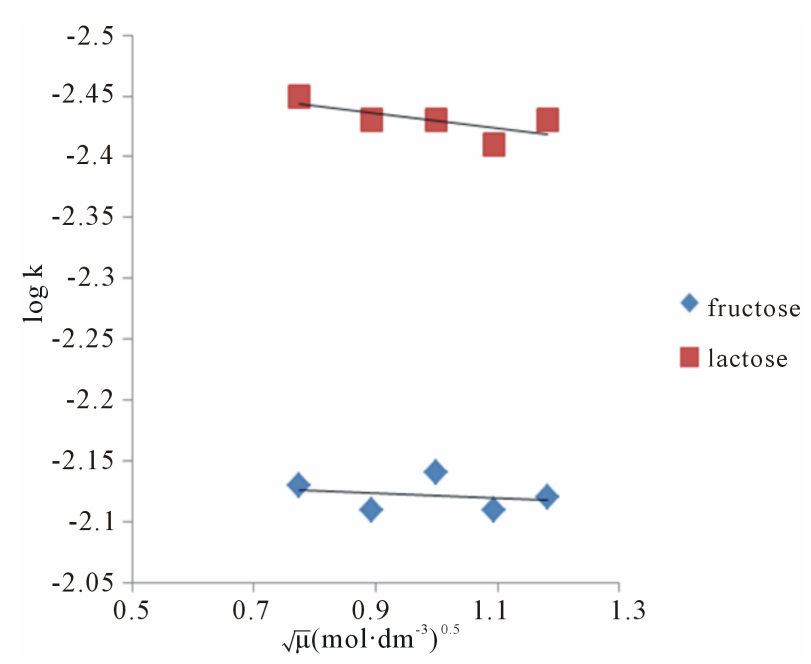

Figure 5. A plot of $\sqrt{\mu}$ vs $\log \mathrm{k}$ for the oxidation of fructose and lsactose by $\mathrm{KMnO}_{4}$. 
Table 3. Effect of temperature on the rate of oxidation of fructose and lactose.

\begin{tabular}{cccccc}
\hline \multirow{5}{*}{ Sugars } & \multicolumn{5}{c}{ Rate Constant $\times \mathbf{1 0}^{3}$} \\
\cline { 2 - 6 } & $\mathbf{3 0}^{\circ} \mathbf{C}$ & $\mathbf{3 5}^{\circ} \mathbf{C}$ & $\mathbf{4 0}^{\circ} \mathbf{C}$ & $\mathbf{4 5}^{\circ} \mathbf{C}$ & $\mathbf{5 0}^{\circ} \mathbf{C}$ \\
\hline Fructose & 4.4 & 5.8 & 7.6 & 11.6 & 14.7 \\
Lactose & 3.6 & 4.1 & 6.0 & 9.6 & 11.6 \\
\hline
\end{tabular}

$\left[\mathrm{KMnO}_{4}\right]=1 \times 10^{-3} \mathrm{~mol} \cdot \mathrm{dm}^{-3} ;[$ Lactose $]=3 \times 10^{-2} \mathrm{~mol} \cdot \mathrm{dm}^{-3} ;[$ fructose $]=$ $4 \times 10^{-2} \mathrm{~mol} \mathrm{dm}{ }^{-3} ;\left[\mathrm{H}_{2} \mathrm{SO}_{4}\right]=1 \times 10^{-1} \mathrm{~mol} \cdot \mathrm{dm}^{-3} ;\left[\mathrm{KNO}_{3}\right]=0.3 \mathrm{~mol} \cdot \mathrm{dm}^{-3}$.

Table 4. The values of activation parameters at $32^{\circ} \mathrm{C}$.

\begin{tabular}{ccccc}
\hline Sugars & $\begin{array}{c}\mathbf{E}_{\mathbf{a}} \\
\mathrm{KJ} \cdot \mathrm{mol}^{-1}\end{array}$ & $\begin{array}{c}\Delta \mathbf{H}^{\#} \\
\mathrm{KJ} \cdot \mathrm{mol}^{-1}\end{array}$ & $\begin{array}{c}\Delta \mathbf{S}^{\#} \\
\mathrm{KJ} \cdot \mathrm{mol}^{-1}\end{array}$ & $\begin{array}{c}\Delta \mathbf{G}^{\#} \\
\mathrm{KJ} \cdot \mathrm{mol}^{-1}\end{array}$ \\
\hline Fructose & 50.0 & 47.6 & -133.8 & 88.4 \\
Lactose & 50.2 & 47.9 & -134.6 & 89.0 \\
\hline
\end{tabular}

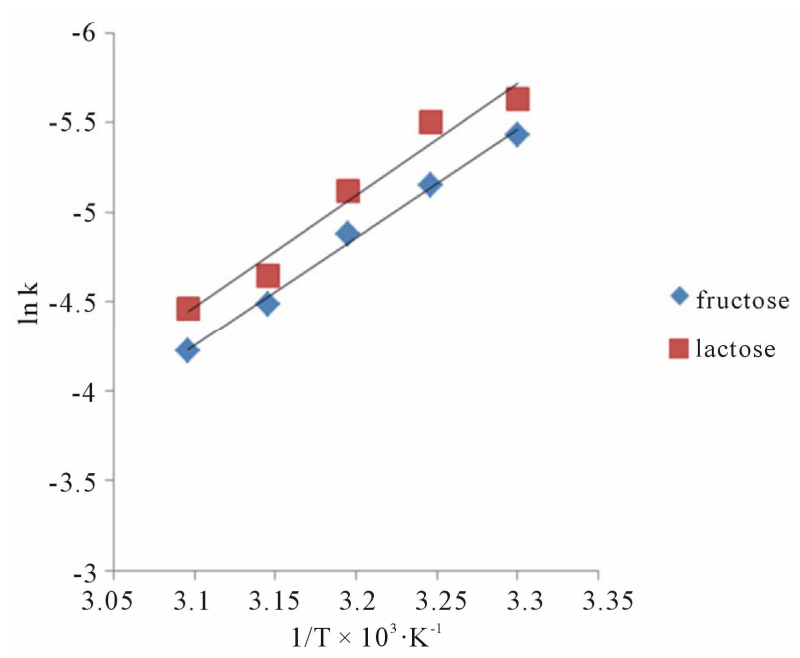

Figure 6. A plot of $\ln \mathrm{k}$ vs $1 / \mathrm{T}$ for fructose and lactose against $\mathrm{KMnO}_{4}$ at $\sqrt{\mu} 0.775\left(\mathrm{~mol} \cdot \mathrm{dm}^{-3}\right)^{0.5}$.

compared to that in the reactive species [16]. The high positive values of free energy of activation also support the formation of solvated transition state $[17,18]$.

\section{DISCUSSION}

\section{Reactive Species of $\mathrm{MnO}_{4}^{-}$}

There were two main products in each sugar which identified as an arabinonic and formic acid and the respective acids of sugars. These products may be due to the generation of two oxidative species of $\mathrm{KMnO}_{4}$ in an acidic medium. Respective acids of sugar by the generation of reactive oxygen species in presence of an acid as reported earlier [14] and arabinonic and formic acids [15] due to the breakage of $\mathrm{C} \_\mathrm{C}$ bond by the reactive species of $\mathrm{MnO}_{4}^{-}$.

$$
\begin{aligned}
& 2 \mathrm{KMnO}_{4}+3 \mathrm{H}_{2} \mathrm{SO}_{4} \rightarrow \mathrm{K}_{2} \mathrm{SO}_{4}+2 \mathrm{MnSO}_{4}+8[\mathrm{O}]+3 \mathrm{H}_{2} \mathrm{O} \\
& \mathrm{RCHO}+[\mathrm{O}] \rightarrow \mathrm{RCOOH}
\end{aligned}
$$

On the basis of stoichiometric studies it can be easily concluded that $\mathrm{MnO}_{4}^{-}$is the active reactive oxidizing specie in an acidic medium which forms permanganic acid when combine with $\mathrm{H}^{+}$ion.

$$
\mathrm{H}^{+}+\mathrm{MnO}_{4}^{-} \rightleftarrows \mathrm{HMnO}_{4}
$$

This permanganic acid is a highly oxidative unstable inorganic acid which with catalyst or alone oxidizes the sugar via the formation of unstable intermediate complex which leads to the formation of aldehyde hydrate. This aldehyde hydrate frequently reacts with $\mathrm{MnO}_{3}^{-}$species and converted into respective carboxylic acid.

\section{REACTIVE SPECIES OF Hg(II) CHLORIDE IN AN ACIDIC MEDIUM}

In catalyzed oxidation of lactose in an acidic medium, since the solution of catalyst was prepared in the water therefore it was reasonable to assume that the reactive specie of catalyst is $\left[\mathrm{Hg}\left(\mathrm{H}_{2} \mathrm{O}\right)_{6}\right]^{+2}[19,20]$.

$$
\mathrm{HgCl}_{2}+6 \mathrm{H}_{2} \mathrm{O} \underset{\mathrm{k}_{-1}}{\stackrel{\mathrm{k}_{1}}{\rightleftarrows}}\left[\mathrm{Hg}\left(\mathrm{H}_{2} \mathrm{O}\right)_{6}\right]^{+2}+2 \mathrm{Cl}^{-}
$$

The above equation was comparable with the work reported earlier [21,22] where kinetic studies have been made for the oxidation of reducing sugars by acidic solution of N-bromophthalimide and NBA in presence of Ir (III) as a homogeneous catalyst. In this case existence of following equilibrium was suggested.

$$
\left[\mathrm{IrCl}_{6}\right]^{3-}+\mathrm{H}_{2} \mathrm{O} \rightleftarrows\left[\mathrm{IrCl}_{5}\left(\mathrm{H}_{2} \mathrm{O}\right)\right]^{-2}+\mathrm{Cl}^{-}
$$

\section{SPECTRAL EVIDENCE FOR THE FORMATION OF COMPLEXES DURING COURSE OF THE REACTION}

In the kinetic studies of the reducing sugars, it has been observed that the metal ions such as Ru(III) [23] \& $\mathrm{Pd}(\mathrm{II})$ [24] form complexes with the reducing sugars in an acidic medium. It was also reported $[24,25]$ that the complex thus formed have tendencies to react with the reacting species of NBA \& also with $\mathrm{Hg}(\mathrm{II})$, whose function in the reaction was as a $\mathrm{Br}^{-}$ion scavenger and as co-catalyst. In the oxidation of lactose with permanganate ion in acidic medium, order with respect to the sugars concentration was first throughout its 10 -fold variation. This shows that $\mathrm{OH}$ group of sugar involves in the oxidation before the rate determining step although it will combine with the most reactive complex to form the reaction products along with the regeneration of $\mathrm{Hg}$ catalyst. 
In order to probe the possible formation of complex $\mathrm{MnO}_{4}^{-}$and $\left[\mathrm{Hg}\left(\mathrm{H}_{2} \mathrm{O}\right)_{6}\right]^{+2}$ spectra for the solution of $\mathrm{MnO}_{4}^{-}, \mathrm{H}^{+}$and for the solution of $\mathrm{MnO}_{4}^{-}, \mathrm{H}^{+}$and $\left[\mathrm{Hg}\left(\mathrm{H}_{2} \mathrm{O}\right)_{6}\right]^{+2}$ have been recorded (Figures 7 and 8). From the spectra, it was clear that an addition of $\left[\mathrm{Hg}\left(\mathrm{H}_{2} \mathrm{O}\right)_{6}\right]^{+2}$ solution causes an increase in absorbance from 1.79 to $2.00\left(\lambda_{\max } 545 \mathrm{~nm}\right)$. This increase in absorbance can be considered as an indication of increased formation of the complex between reactive species of $\left[\mathrm{Hg}\left(\mathrm{H}_{2} \mathrm{O}\right)_{6}\right]^{+2}$ in an acidic medium according to the following equilibrium:

$$
\left[\mathrm{Hg}\left(\mathrm{H}_{2} \mathrm{O}\right)_{6}\right]^{+2}+\mathrm{MnO}_{4}^{-}+\mathrm{H}_{3} \mathrm{O}^{+} \longrightarrow\left[\left.\prod_{\mathrm{O}}^{\mathrm{O}=}\right|_{\mathrm{Mn}}-\mathrm{O}\left(\mathrm{H}_{2} \mathrm{O}\right)_{5}\right]^{+2}+2 \mathrm{H}_{2} \mathrm{O}
$$

When lactose solution was added to the solutions of $\mathrm{MnO}_{4}^{-}, \mathrm{H}^{+}$and $\left[\mathrm{Hg}\left(\mathrm{H}_{2} \mathrm{O}\right)_{6}\right]^{+2}$ a decrease in absorbance from 2.00 to $1.99\left(\lambda_{\max } 545 \mathrm{~nm}\right)$ for lactose was observed
(Figure 10). This shows that the complex formed subsequently combines with lactose to give a highly solvated activated complex of the types.

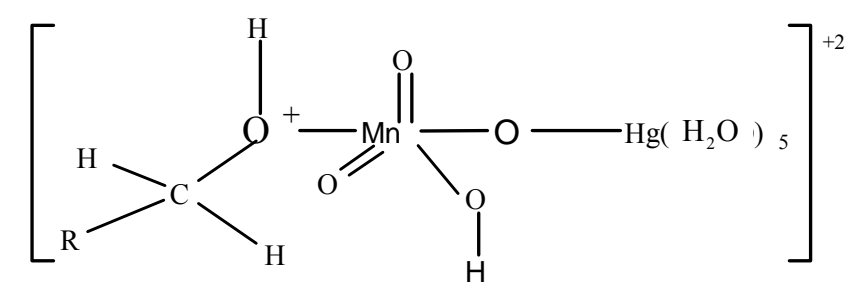

according to the following equilibrium

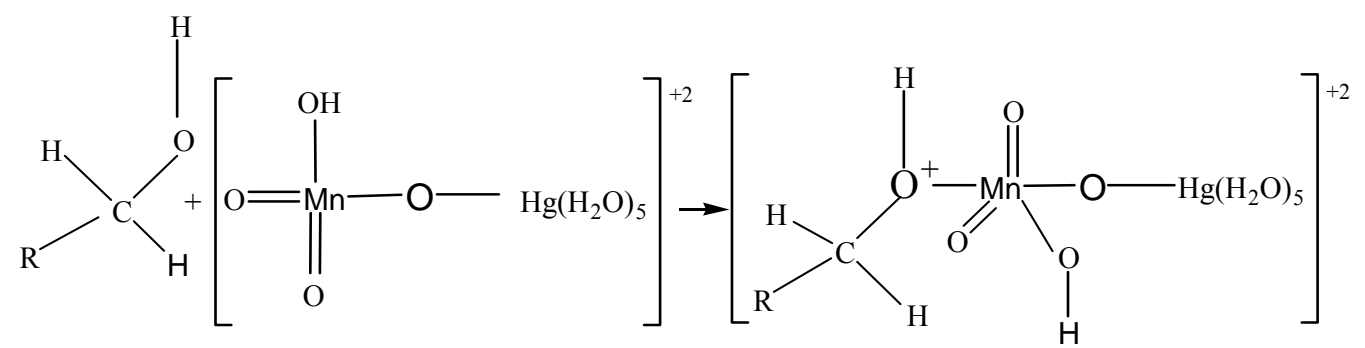

The spectral change due to the addition of fructose in $\mathrm{MnO}_{4}^{-}$and $\mathrm{H}^{+}$solution clearly indicates that complex formed with fructose due to which absorbance was decreased (Figure 9). This decrease in absorbance with
$\mathrm{MnO}_{4}^{-}$can be considered as an indication of increased formation of the complex between reacting species of $\mathrm{MnO}_{4}^{-}$and sugar in acidic medium.

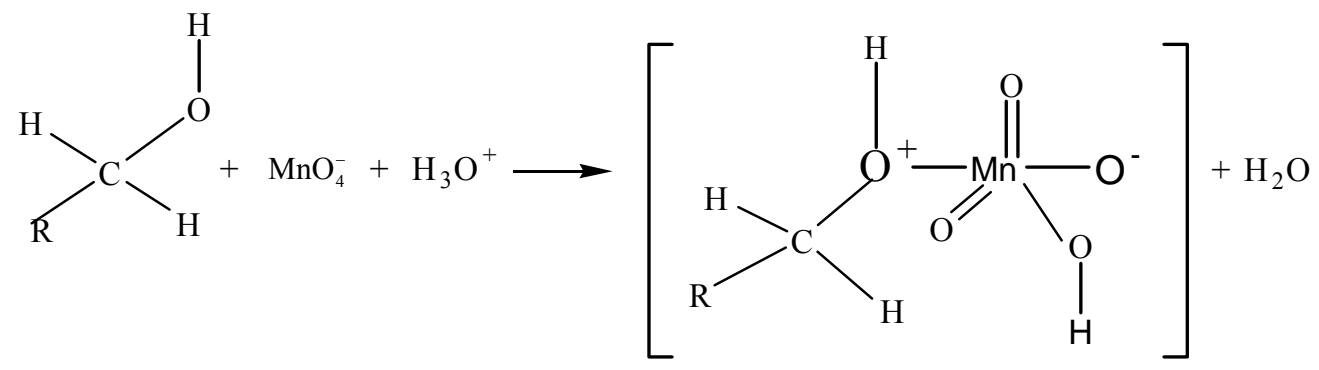

\section{REACTIONS FOR OXIDATION OF SUGARS INTO ALDONIC ACIDS}

$$
\mathrm{C}_{6} \mathrm{H}_{12} \mathrm{O}_{6}+2 \mathrm{MnO}_{4}^{-} \stackrel{\mathrm{H}^{+}}{\longrightarrow} \mathrm{C}_{5} \mathrm{H}_{10} \mathrm{O}_{6}+\mathrm{HCOOH}+2 \mathrm{MnO}_{3}^{-}
$$

Fructose Arabinonic acid Formic acid 


$$
\begin{aligned}
& \mathrm{C}_{12} \mathrm{H}_{22} \mathrm{O}_{11}+4 \mathrm{MnO}_{4}^{-}+\mathrm{H}_{2} \mathrm{O} \stackrel{\mathrm{H}^{+} / \mathrm{Hg}^{+2}}{\longrightarrow} 2 \mathrm{C}_{5} \mathrm{H}_{10} \mathrm{O}_{6}+2 \mathrm{HCOOH}+4 \mathrm{MnO}_{3}^{-} \\
& \text {Lactose } \\
& \text { Arabinonic acid Formic acid }
\end{aligned}
$$

\section{Reaction Pathway for the Oxidation of Fructose}

$$
\mathrm{C}_{6} \mathrm{H}_{12} \mathrm{O}_{6}+\mathrm{HMnO}_{4}^{-}+\mathrm{H}_{3}^{+} \mathrm{O} \underset{\mathrm{k}_{-1}}{\stackrel{\mathrm{k}_{1}}{\rightleftarrows}} \mathrm{HMnO}_{4}+\mathrm{H}_{2} \mathrm{O}
$$

where $\mathrm{R}=\mathrm{C}_{4} \mathrm{H}_{9} \mathrm{O}_{5}$

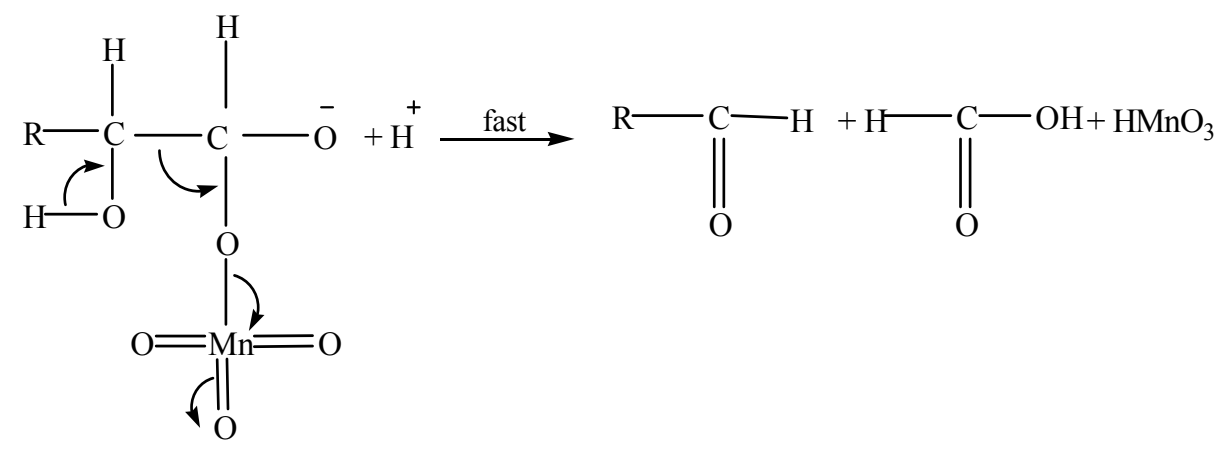

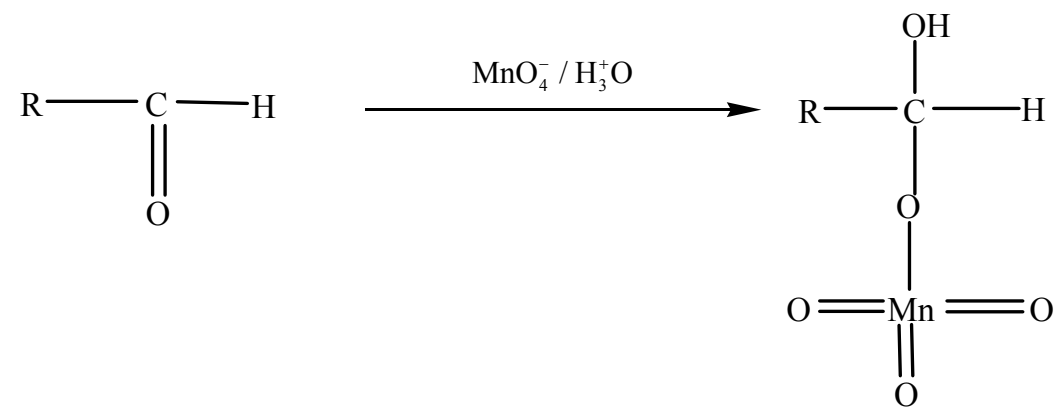

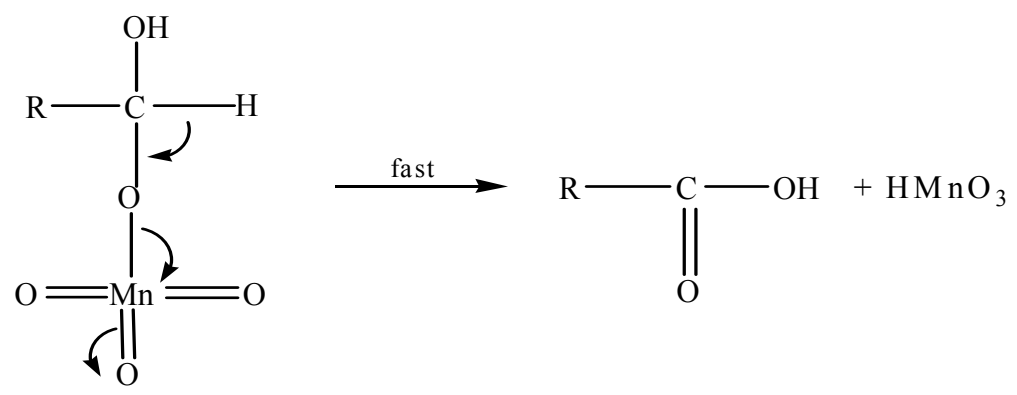

Scheme 1. Formation of formic and arabinonic acid as a result of oxidation of fructose. 


\section{Reaction Pathway for Catalytic Oxidation of Lactose}

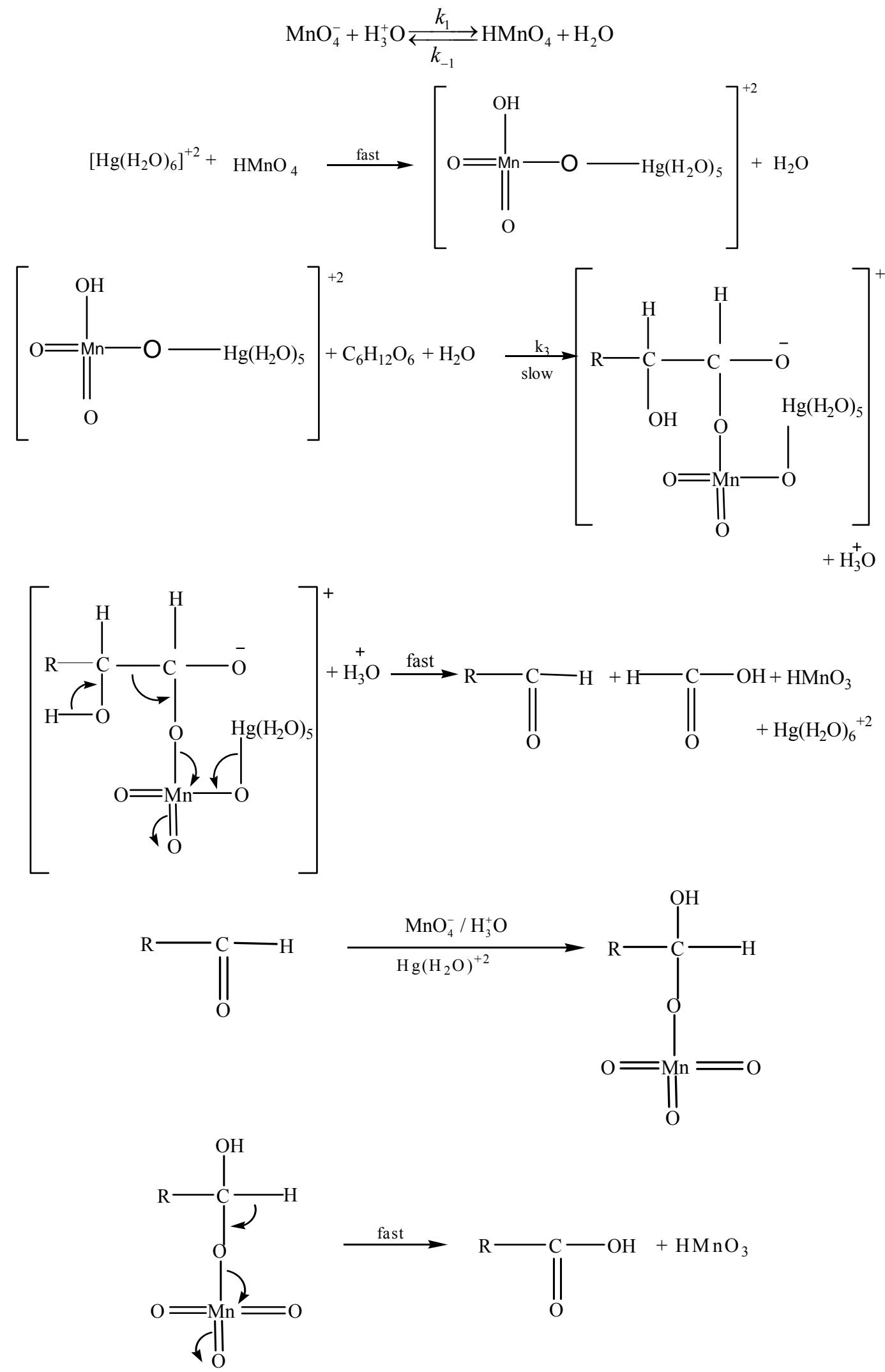

Scheme 2. Formation of formic and arabinonic acid as a result of oxidation of lactose. 


\section{REACTIONS FOR OXIDATION OF SUGARS INTO OTHER CARBOXYLIC ACIDS}

$$
\begin{gathered}
\mathrm{C}_{6} \mathrm{H}_{12} \mathrm{O}_{6}+2 \mathrm{MnO}_{4}^{-} \stackrel{\mathrm{H}^{+}}{\longrightarrow} \mathrm{C}_{6} \mathrm{H}_{10} \mathrm{O}_{7}+\mathrm{H}_{2} \mathrm{O}+2 \mathrm{MnO}_{3}^{-} \\
\mathrm{C}_{12} \mathrm{H}_{22} \mathrm{O}_{11}+4 \mathrm{MnO}_{4}^{-} \stackrel{\mathrm{H}^{+} / \mathrm{Hg}^{+2}}{\longrightarrow} \mathrm{C}_{12} \mathrm{H}_{18} \mathrm{O}_{13}+2 \mathrm{H}_{2} \mathrm{O}+4 \mathrm{MnO}_{3}^{-}
\end{gathered}
$$

\section{Reaction Pathway for Oxidation of Fructose in Absence of Catalyst}

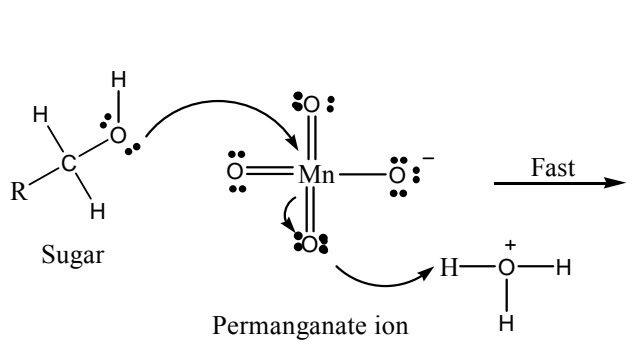

(A)

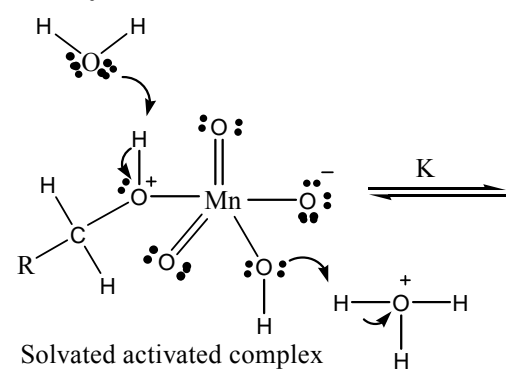

(B)

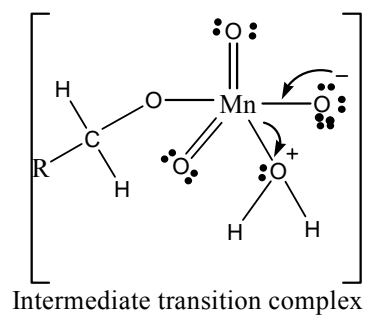

(C)

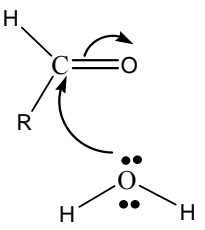

Solvated aldehyde<smiles></smiles>
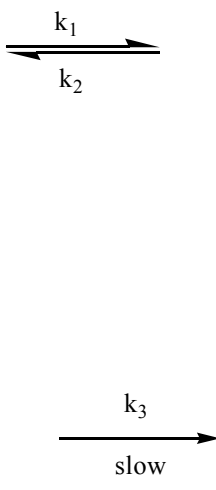

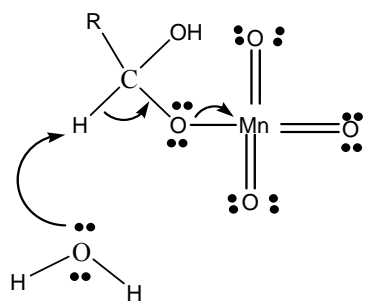

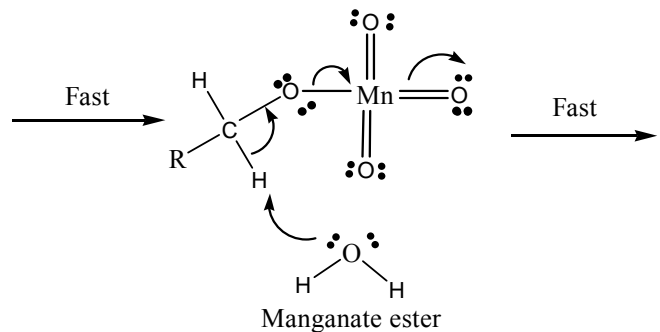

(D)<smiles>CO[W](=O)=O</smiles>

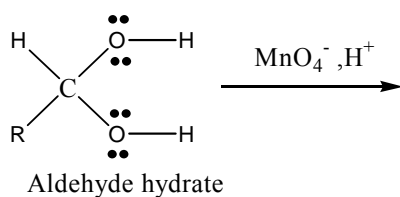

(E)

where $\mathrm{R}=\mathrm{C}_{5} \mathrm{H}_{9} \mathrm{O}_{5}$

Scheme 3. Formation of fructuronic acid as a result of oxidation of fructose. 


\section{Reaction Pathway for Oxidation of Lactose in Presence of Catalyst}

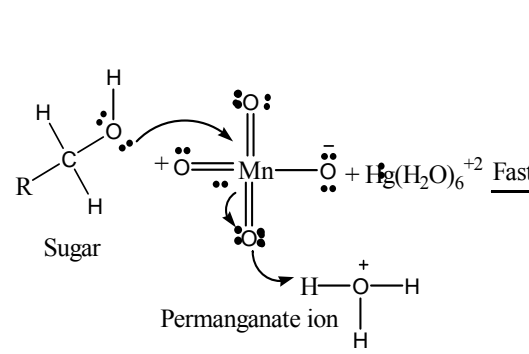

(A)

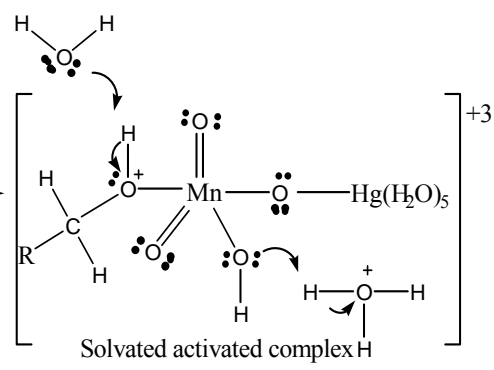

(B)

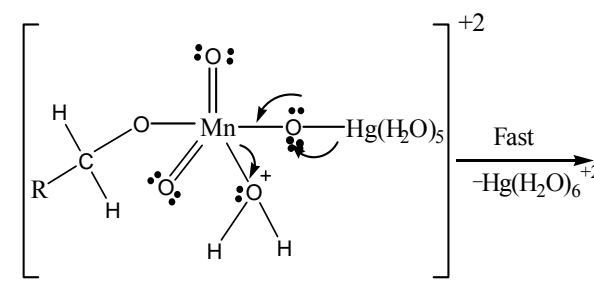

Intermediate transition complex

(C)

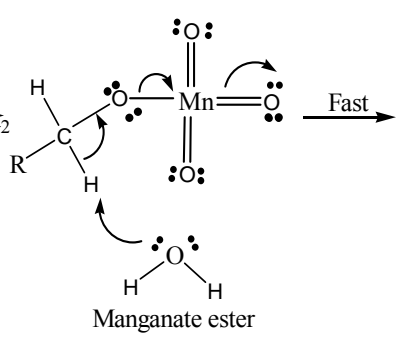

(D)<smiles>[R]C(C)CO[CH]</smiles><smiles>[Li][W](=O)(=O)O</smiles>

Solvated aldehyde

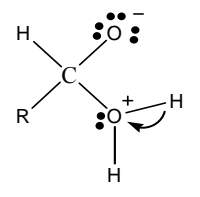<smiles>C#CC</smiles><smiles>C=[13CH]</smiles><smiles>[R]C(O)(CC(=O)[O-])C(=O)O</smiles>

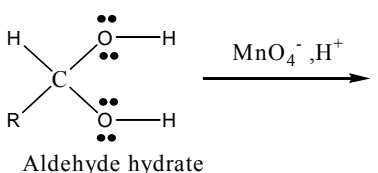

(E)<smiles>[R]C(=O)O</smiles><smiles>O=[N+]([O-])[O-]</smiles>

where $\mathrm{R}=\mathrm{C}_{11} \mathrm{H}_{17} \mathrm{O}_{11}$

Scheme 4. Formation of lacturic acid as a result of oxidation of lactose.

\section{PROPOSED MECHANISM OF KINETICS OF OXIDATION AGAINST $\mathrm{KMnO}_{4}$}

Thus based on above experimental facts, the proposed reaction mechanism involves the formation of [O] [14] by action of $\mathrm{H}_{2} \mathrm{SO}_{4}$ on $\mathrm{KMnO}_{4}$.

$$
\begin{aligned}
& 2 \mathrm{~K} \mathrm{MnO}_{4}+3 \mathrm{H}_{2} \mathrm{SO}_{4} \rightarrow \mathrm{K}_{2} \mathrm{SO}_{4}+2 \mathrm{MnSO}_{4}+8[\mathrm{O}]+3 \mathrm{H}_{2} \mathrm{O} \\
& \mathrm{RCHO}+[\mathrm{O}] \rightarrow \mathrm{RCOOH}
\end{aligned}
$$

The permanganate ion reacts with fructose to form complex $\left[\mathrm{C}_{6} \mathrm{H}_{11} \mathrm{O}_{6}-\mathrm{MnO}_{4}^{-}\right]$. This complex finally gives an aldonic acid in presence of nucleophile.

The probable rate law might be proposed. 


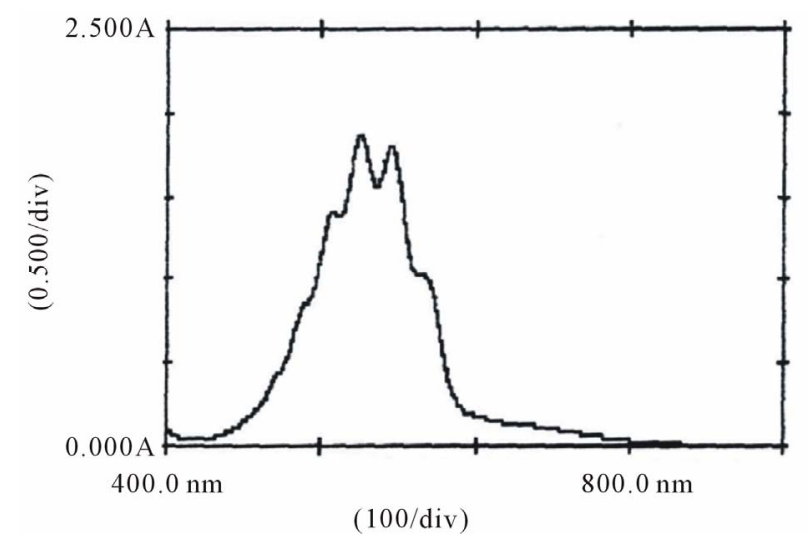

Figure 7. Absorption spectra of $\mathrm{MnO}_{4}^{-}$and $\mathrm{H}^{+}$solutions.

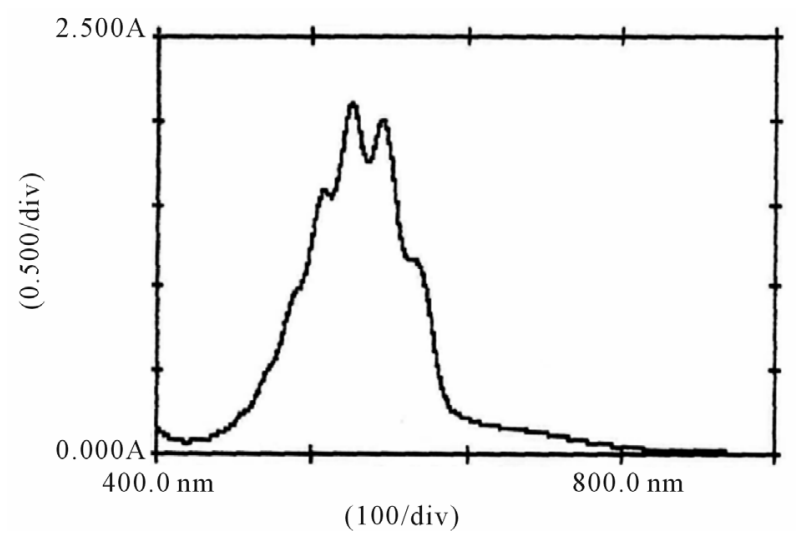

Figure 8. Absorption spectra of $\mathrm{MnO}_{4}^{-}, \mathrm{H}^{+}$and $\left[\mathrm{Hg}\left(\mathrm{H}_{2} \mathrm{O}\right)_{6}\right]^{+2}$ solutions.

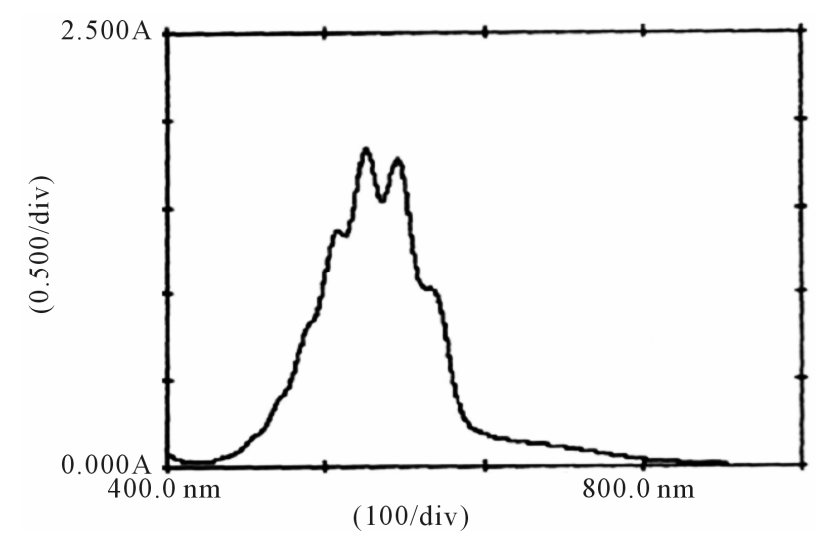

Figure 9. Absorption spectra of $\mathrm{MnO}_{4}^{-}, \mathrm{H}^{+}$and fructose solutions.

$$
\frac{-\mathrm{d}\left[\mathrm{MnO}_{4}^{-}\right]}{\mathrm{d} t}=\mathrm{k}[\mathrm{RCHO}]\left[\mathrm{MnO}_{4}^{-}\right][\mathrm{Hg}]
$$

where RCHO represents the concentration of fructose or lactose and $\mathrm{MnO}_{4}^{-}$is of Oxidant. The following mechanism was proposed to explain the pathway of oxidation of lactose in presence of $\mathrm{Hg}$ catalyst:

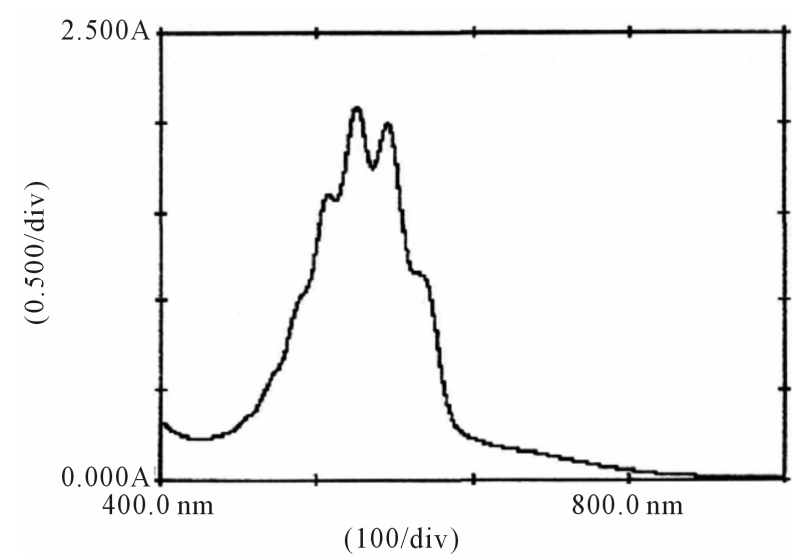

Figure 10. Absorption spectra of $\mathrm{MnO}_{4}^{-}, \mathrm{H}^{+},\left[\mathrm{Hg}\left(\mathrm{H}_{2} \mathrm{O}\right)_{6}\right]^{+2}$ and lactose solutions.

$$
\begin{aligned}
& \mathrm{RCHO}+\mathrm{MnO}_{4}^{-}+\mathrm{H}^{+} \underset{\mathrm{k}_{2}}{\stackrel{\mathrm{k}_{1}}{\rightleftarrows}}\left[\begin{array}{c}
\mathrm{RCHO}----\mathrm{MnO}_{4}^{-} \\
\text {Complex }
\end{array}\right] \\
& \text { [Complex } \left.] \stackrel{\mathrm{k}_{3}}{\longrightarrow} \text { [product }\right] \\
& \text { slow }
\end{aligned}
$$

where $\mathrm{k}_{1}$ and $\mathrm{k}_{2}$ represent the rate constant in the forward and reverse direction and $\mathrm{k}_{3}$ is the rate constant of the formation of product. Rate of formation of complex will be given as:

$$
\begin{aligned}
& \frac{\mathrm{d}[\text { Complex }]}{\mathrm{dt}} \\
& =\mathrm{k}_{1}[\mathrm{RCHO}]\left[\mathrm{MnO}_{4}^{-}\right][\mathrm{Hg}]-\left[\mathrm{k}_{2}-\mathrm{k}_{3}\right][\text { Complex }]
\end{aligned}
$$

At steady state,

$$
\frac{\mathrm{d}[\text { Complex }]}{\mathrm{dt}}=0
$$

From Eqs.1 and 2 concentration of complex comes out to be:

$$
[\text { Complex }]=\frac{\mathrm{k}_{1}[\mathrm{RCHO}]\left[\mathrm{MnO}_{4}^{-}\right]}{\mathrm{k}_{2}+\mathrm{k}_{3}}[\mathrm{Hg}]
$$
be:

At steady state rate of disappearance of $\mathrm{MnO}_{4}^{-}$may

$$
\begin{gathered}
\frac{-\mathrm{d}\left[\mathrm{MnO}_{4}^{-}\right]}{\mathrm{dt}}=\mathrm{k}_{3}[\text { Complex }] \\
\frac{-\mathrm{d}\left[\mathrm{MnO}_{4}^{-}\right]}{\mathrm{dt}}=\frac{\mathrm{k}_{1} \mathrm{k}_{3}[\mathrm{RCHO}]\left[\mathrm{MnO}_{4}^{-}\right][\mathrm{Hg}]}{\left(\mathrm{k}_{2}+\mathrm{k}_{3}\right)}
\end{gathered}
$$

Now the total $\left[\mathrm{MnO}_{4}^{-}\right]$may be considered as:

$$
\left[\mathrm{MnO}_{4}^{-}\right]_{T}=\left[\mathrm{MnO}_{4}^{-}\right]+[\text {Complex }]
$$

Now put the value of Complex 


$$
\left[\mathrm{MnO}_{4}^{-}\right]_{T}=\left[\mathrm{MnO}_{4}^{-}\right]+\frac{\mathrm{k}_{3}[\mathrm{RCHO}]\left[\mathrm{MnO}_{4}^{-}\right][\mathrm{Hg}]}{\left(\mathrm{k}_{2}+\mathrm{k}_{3}\right)}
$$

From Eq. 7 the value of $\left[\mathrm{MnO}_{4}^{-}\right]$comes out:

$$
\left[\mathrm{MnO}_{4}^{-}\right]=\frac{\left(\mathrm{k}_{2}+\mathrm{k}_{3}\right)\left[\mathrm{MnO}_{4}^{-}\right][\mathrm{Hg}]}{\left(\mathrm{k}_{2}+\mathrm{k}_{3}\right)+\mathrm{k}_{1}[\mathrm{RCHO}]}
$$

The final rate law from 5 to 8 :

$$
\begin{gathered}
\frac{-\mathrm{d}\left[\mathrm{MnO}_{4}^{-}\right]}{\mathrm{dt}}=\frac{\mathrm{k}_{1} \mathrm{k}_{3\{\}}[\mathrm{RCHO}]\left[\mathrm{k}_{2}+\mathrm{k}_{3}\right]\left[\mathrm{MnO}_{4}^{-}\right][\mathrm{Hg}]}{\left\{\left(\mathrm{k}_{2}+\mathrm{k}_{3}\right)+\mathrm{k}_{1}[\mathrm{RCHO}]\right\}\left[\mathrm{k}_{2}+\mathrm{k}_{3}\right]} \\
=\frac{\mathrm{k}_{1} \mathrm{k}_{3}[\mathrm{RCHO}]\left[\mathrm{MnO}_{4}^{-}\right]}{\left[\mathrm{k}_{1}+\mathrm{k}_{3}\right]+\mathrm{k}_{1}[\mathrm{RCHO}]}
\end{gathered}
$$

In present experimental conditions,

$$
\mathrm{k}_{2}+\mathrm{k}_{3}>\mathrm{k}_{1}[\mathrm{RCHO}]
$$

Hence above equation reduces to,

$$
\begin{aligned}
& \frac{-\mathrm{d}\left[\mathrm{MnO}_{4}^{-}\right]}{\mathrm{dt}}=\frac{\mathrm{k}_{1} \mathrm{k}_{3}[\mathrm{RCHO}]\left[\mathrm{MnO}_{4}^{-}\right]_{T}}{\mathrm{k}_{2}+\mathrm{k}_{3}} \\
& =\mathrm{k}[\mathrm{RCHO}]\left[\mathrm{MnO}_{4}^{-}\right]_{T}
\end{aligned}
$$

where, $\mathrm{k}=\frac{\mathrm{k}_{1} \mathrm{k}_{3}}{\mathrm{k}_{2}+\mathrm{k}_{3}}$.

The above equation indicates first order kinetics with respect to sugar and permanganate ion concentration.

\section{COMPARATIVE STUDIES}

The results of the present study of the oxidation of fructose and lactose by potassium permanganate in acidic medium were compared with the results supported for the oxidation of some aldoses by chromium peroxydichromate in very dilute sulphuric acid [26] and the reactivities of some aldoses and aldoseamines towards potassium bromate in hydrochloric acid medium [1]. In present work, it was found that the $\mathrm{MnO}_{4}^{-}$is the reactive species of potassium permanganate in acidic as well as in alkaline medium, as far as the kinetic order with respect to $\mathrm{MnO}_{4}^{-}$is concerned, it was first order throughout the variation of $\left[\mathrm{MnO}_{4}^{-}\right]$. The reported first order kinetics with respect to [sugar] was similar with the present study $[1,27]$. The effect of $\mathrm{H}^{+}$ion concentration have the same effect as in the oxidation of some aldoses by peroxydichromate in dilute sulphuric acid [26] and reactivities of some aldoses and aldoseamines towards potassium bromate in hydrochloric acid medium.

\section{CONCLUSIONS}

The following conclusions were drawn from the ob- served kinetic data and the spectral informations collected for the oxidation of fructose and lactose by potassium permanganate in acidic medium while $\mathrm{Hg}$ was used in the oxidation of lactose.

1) $\mathrm{MnO}_{4}^{-}$and $\left[\mathrm{Hg}\left(\mathrm{H}_{2} \mathrm{O}\right)_{6}\right]^{+2}$ have been assumed as the reactive species of potassium permanganate and $\mathrm{Hg}$ (II) in acidic medium.

2) The complex,<smiles>[R]C(O)C([O-])(CC)O[W](=O)(=O)CC</smiles>

and the complex,<smiles>[R]C(O)C([O-])(OC(=O)O[GaH])C([2H])([2H])CC</smiles>

has been proposed as the most unstable activated complex in the oxidation of fructose and lactose respectively.

3) The formation of highly solvated activated complex (Schemes 1-4) is supported by observed negative value of entropy of activation.

4) First order kinetics has been observed with respect to oxidant and sugar.

5) Linear dependence of rate is observed when acidity of medium increased.

6) The rate of oxidation of fructose and lactose is unaffected by the change in ionic strength of the medium.

7) Formic acid and arabinonic acid are identified as main oxidation products along with the other acids such as fructuronic and lacturic acid.

\section{REFERENCES}

[1] Gupta, K.K.S., Debnath, N. and Bhattacharjee, N. (2000) Reactivities of some aldoses and aldosamines towards potassium bromate in hydrochloric acid medium. Journal of Indian Chemical Society, 77, 152-156.

[2] Hanover, L.M. and White, J.S. (1993) Manufacturing, composition, and applications of fructose. Journal of Clinical Nutrition, 58, 724-732.

[3] Oregon State University (2008) Sugar sweetness. http://food.oregonstate.edu/sugar/sweet.html

[4] Cooper, L.F., Edith, M.B. and Helen, S.M. (1947) Nutrition in health and disease. 10th Edition, J.B. Lipincott, 
Philadelphia, 414.

[5] Odebunmi, E.O., Twarere, S.A. and Owalude, S.O. (2006) Kinetics of oxidation of fructose, sucrose and maltose by potassium permanganate in $\mathrm{NaHCO}_{3} / \mathrm{NaOH}$ buffer and Iridium(IV) complex in sodium acetate/acetic acid buffer. International Journal of Chemistry, 16, 167-176.

[6] Srivastava, S. and Singh, S. (2008) Kinetic study of $\mathrm{Rh}$ (III) catalyzed oxidation of sucrose by sodium periodate in acidic medium. Asian Journal of Chemistry, 20, 973- 978.

[7] Krishna, K.V. and Rao, P.J.P. (1995) Kinetics and mechanism of oxidation of some reducing sugars by diperiodatoargentate(III) in alkaline medium. Transition Metal Chemistry (Historical Archive), 20, 344-346. doi:10.1007/BF00139125

[8] Singh, S.V., Saxena, O.C. and Singh, M.P. (1970) Kinetics and mechanism of oxidation of D-xylose, L-arabinose, D-glucose, D-fructose, D-mannose, D-galactose, L-sorbose, lactose, maltose, cellobiose, and melibiose by copper(II) in alkaline medium. Journal of the American Chemical Society, 92, 537. doi:10.1021/ja00706a020

[9] Nath, N. and Singh, M.P. (1965) Mechanism of the oxidation of reducing sugars (hexoses) by hexacyanoferrate(III) in alkaline medium and Lobry de Bruyn transformation. The Journal of Physival Chemistry, 69, 2038. doi:10.1021/j100890a040

[10] Reidies, A.H. (2002) Manganese compounds in Ullmann's Encyclopedia of industrial chemistry. Wiley-VCH, Weinheim.

[11] Dash, S., Patel, S. and Mishra, B.K. (2009) Oxidation by permanganate: Synthetic and mechanistic aspects. Tetrahedron, 65, 707-739.

[12] Ruhoff, J.R. (1943) n-Heptanoic acid. Organic Syntheses, Collection, 2, 315.

[13] Feigl, F. (1966) Spot tests in organic analysis. Elsevier, New York.

[14] Azmat, R., Naz, R., Khalil, A. and Fahimuddin (2008) Kinetics and mechanism of oxidation of D-galactose and D-maltose with potassium permanganate in acidic medium by spectrophotometry. Asian Journal of Chemistry, 20, 829-837.

[15] Abdel-Hamid, M.I., Khairou, K.S. and Hassan, R.M. (2003) Kinetics and mechanism of permanganate oxidation of pectin in acid perchlorate media. European Polymer Journal, 39, 381-387. doi:10.1016/S0014-3057(02)00217-3

[16] Tripathi, R., Kambo, N. and Upadhay, S.K. (2004) Kinetics and mechanism of the ruthenium(III)-catalysed oxidation of some reducing sugars by sodium metaperiodate in alkaline medium. Bulgarian Chemistry and Industry, 75, $18-23$.
[17] Prasad, M., Singh, M.K., Singh, H.K. and Singh, V.P. (1993) Kinetics and mechanism of oxidation of some reducing sugar by diperiodatorgentate(III) in alkaline medium. Journal of Indian Chemical Society, 70, 74-76.

[18] Singh, A.K., Chopra, D., Rahmani, S. and Singh, B. (1998) Kinetics and mechanism of Pd(II) catalyzed oxidation of D-arabinose, D-xylose and D-galactose by N-bromosuccinimide in acidic solution. Carbohydrate Research, 314 157-160. doi:10.1016/S0008-6215(98)00322-X

[19] Richens, D.T. (1997) The chemistry of aqua ions. Wiley, Chichester.

[20] Singh, A.K., Sachdev, N.A., Srivastava, B.J. and Katre, Y. (2012) Oxidation of d-glucose by N-bromophthalimide in the presence of chlorocomplex of iridium(III): A kinetic and mechanistic study. Research on Chemical Intermediates, 38, 507-521. doi:10.1007/s11164-011-0367-y

[21] Singh, A.K., Rahmani, S., Singh, B., Singh, R.K. and Singh, M. (2004) Mechanism of $\operatorname{Ir}(\mathrm{III})$-catalysed and $\mathrm{Hg}$ (II)co-catalysed oxidation of reducing sugars by N-bromoacetamide in acidic medium. Journal of Physical Organic Chemistry, 17, 249-256. doi:10.1002/poc.723

[22] Singh, A.K., Rahmani, S., Singh, B., Singh, R.K. and Singh, M. (2004) Mechanism of Ir(III)-catalysed and Hg (II)-co-catalysed oxidation of reducing sugars by N-bromoacetamide in acidic medium. Journal of Physical Organic Chemistry, 17, 249-256. doi:10.1002/poc.723

[23] Isbell, H.S. (1932) Mechanism of ruthenium (III) catalysis of periodate oxidation of aldoses in aqueous alkaline medium. Journal of Research of Bureau of Standards, $\mathbf{8}$, 615-624.

[24] Singh, A.K., Srivasava, J., Rahmani, S. and Singh, V. (2006) $\mathrm{Pd}(\mathrm{II})$-catalyzed and $\mathrm{Hg}(\mathrm{II})$-co-catalyzed oxidation of Dglucose and D-fructose by N-bromoacetamide in the presence of perchloric acid: A kinetic and mechanistic study. Carbohydrate Research, 341, 397-409.

doi:10.1016/j.carres.2005.11.012

[25] Singh, A.K., Singh, V., Singh, A.K., Gupta, N. and Singh, B. (2002) Kinetics and mechanism of $\mathrm{Ru}$ (III) and $\mathrm{Hg}$ (II) co-catalyzed oxidation of D-galactose and D-ribose by N-bromoacetamide in perchloric acid. Carbohydrate Research, 337, 345-351. doi:10.1016/S0008-6215(01)00319-6

[26] Sharma, V.K. and Rai, R.C. (1983) Kinetics and mechanism of oxidation of some aldoses by chromium peroxydichromate in very dilute sulfuric acid. Journal of the Indian Chemical Society, 60, 747-749.

[27] Singh, P., Singh, R., Singh, A.K. and Singh, E.B. (1985) Kinetics and mechanism of cerium(IV) oxidation of dextrose and sorbose in aqueous sulfuric acid medium. Journal of the Indian Chemical Society, 62, 206-208. 